\title{
Customer Concentration and Corporate Violations
}

\author{
Feng Qian \\ School of Management, Jinan University, Guangzhou, China \\ Email: feature0112@163.com
}

How to cite this paper: Qian, F. (2018) Customer Concentration and Corporate Violations. American Journal of Industrial and Business Management, 8, 2168-2179. https://doi.org/10.4236/ajibm.2018.811144

Received: October 26, 2018

Accepted: November 16, 2018

Published: November 19, 2018

Copyright $\odot 2018$ by author and Scientific Research Publishing Inc. This work is licensed under the Creative Commons Attribution International License (CC BY 4.0).

http://creativecommons.org/licenses/by/4.0/

\begin{abstract}
Customer concentration and corporate violations are two important research areas of corporate governance, but there are few studies that combine the customer concentration and corporate violations. The research in this paper finds that customer concentration has two effects on corporate violations: financial distress effects and governance effect. At the same time, through further analysis, it is found that the nature of property rights of enterprises will also have an impact on the relationship between the customer concentration and corporate violations.
\end{abstract}

\section{Keywords}

Customer Concentration, Corporate Violations, Property Rights

\section{Introduction}

The healthy development of the capital market and the improvement of the real economy are inseparable from the standardized operation of listed companies. In order to deal with the violations of laws and regulations of listed companies, the China Securities Regulatory Commission strengthened its law enforcement efforts, continued to strengthen the law enforcement comprehensively and strictly, and successively promulgated a number of policies to deal with the violations of listed companies and regulate the operation and governance of listed companies. In December 13, 2006, the China Securities Regulatory Commission examined and adopted the "Corporate Disclosure management approach" on 196 chairmen's executive meeting to regulate information; the disclosure behavior of issuers listed companies and other information disclosure obligors. August 13, 2007, the China Securities Regulatory Commission published a notice of listed companies to disclose information record for audit and related matters, it 
aims to actively promote listed companies standardize operation and healthy development, to fight against all kinds of violations of laws and regulations, to maximize the protection of the legitimate rights and interests of small and medium investors. In April 29, 2011, the China Securities Regulatory Commission announced the "Administrative Disclosure Rules for Information Disclosure" aimed at guiding and supervising the issuer, the listed company and its controlling shareholder, actual controller, purchaser and other information disclosure obligors to fulfill their information disclosure obligations in accordance with law and protect the legitimate rights and interests of investors. In March 2018, the Shenzhen Stock Exchange and the Shanghai Stock Exchange separately issued the "Implementation Measures for the Significant Illegal Delisting of Listed Companies (Consultation Draft)", and publicly solicited opinions from the public. The solicitation draft stipulated six major illegal delisting situations, which is basically about the information disclosure fraud and other violations of laws and regulations.

However, in recent years, the phenomenon of violations of laws and regulations by listed companies infringing on the interests of investors still occurs from time to time. The violations of listed companies have severely hampered investor confidence and are also a hindrance to the healthy development of China's capital market. According to the statistics of the China Securities Regulatory Commission, in the first half of 2018, the China Securities Regulatory Commission filed 39 cases of information disclosure violations, a year-on-year increase of $50 \% ; 17$ cases were completed, of which 16 were verified, with a success rate of $94 \%$. Among them, the main cases of illegal disclosure of information disclosure are: first, fictitious purchase and sale business, abuse of accounting standards to implement financial fraud; second, use of various means such as non-compliance guarantee, capital occupation, etc. to damage the interests of listed companies; third, the disclosure of environmental violation information of listed companies is not true. At the same time, between 2016 and 2017, the China Securities Regulatory Commission investigated 32 real controllers and the chairman of the board of directors, involving 13 listed companies on the Main Board, 11 listed companies on the SME board, and 2 listed companies on the GEM. The existing literature shows that corporate violations are not only affected by the company's own governance structure, internal control, operating conditions and executive characteristics, but also affected by the external environment, especially by the external stakeholders. Therefore, the impact of external stakeholder characteristics on corporate violations is worth exploring.

As an important external stakeholder of the company, the relationship between customer and company has an important impact on the daily business activities of the company. There is a possibility that the customer and the enterprise may mutually promote a win-win effect, and there may be cases of exploitation of interest. Customer concentration is one of the hot topics in corporate customer research today; customer concentration refers to the ratio of the oper- 
ating income of the top customers of the company to the total operating income of the company, the higher the ratio, the higher the concentration of customers in this company. The existing research divides the impact of customer concentration on enterprises into two categories: one is the financial distress effect, and the other is the governance effect. These two effects have two distinct effects on corporate behavior. However, at present, there is little research on the relationship between customer concentration and corporate violations. Therefore, the author starts with external stakeholders to explore the impact of customer concentration on corporate violations.

\section{Research Purpose and Significance}

\subsection{Research Purpose}

The purpose of this paper is to explore the relationship between customer concentration and corporate violations, and to analyze the effect of customer concentration on corporate violations.

Starting from China's national conditions and unique institutional background, although China's state-owned system reform has made state-owned enterprises have more autonomy in their daily business activities, their ultimate control still belongs to the government, so the operation of state-owned enterprises will inevitably be subject to the government. Therefore, the nature of property rights will have an impact on the relationship between customer concentration and corporate violations. State-owned enterprises and private enterprises will have obvious differences in their daily production and operation decisions. Due to the influence of the government, state-owned enterprises need to play a leading role in the regulation of enterprises. The main goal of non-state-owned enterprises is to maximize their own value. The difference in customer concentration will have a different impact on corporate violations. Based on this, this paper will also study whether there will be significant differences in the impact of customer concentration on corporate violations under different property rights.

\subsection{Research Significance}

The academic significance of this article lies in two aspects:

- Enrich the iterature study of the economic consequences of customer concentration and expand relevant research on the factors affecting corporate violations. Customer concentration can have both financial distress effects and governance effects, and these two effects can have two distinct consequences for the business. It is thought that the research on the economic consequences of customer concentration mostly focuses on the consequences of equity cost, investment efficiency, cost stickiness, executive compensation, accounting information quality and bank loans, while less attention was paid to customer concentration which will affect the company's violations. Previous studies on the factors affecting corporate violations mostly focused on 
factors such as company characteristics, executive characteristics, media supervision, and external institutional environment, while ignoring the impact of external stakeholders on corporate violations.

- Based on China's unique institutional background, from the perspective of the nature of property rights and the degree of competition in the industry, further study whether there will be significant differences in the impact of customer concentration on corporate violations under different property rights and industry competition levels. It enriches the relevant literature research on the impact of the external environment on corporate behavior.

The practical significance of this article lies in two aspects:

- Reveal the influencing factors of corporate violations from the perspective of customer relations, which can provide certain guiding significance for the supervision work of the regulatory authorities and the formulation and improvement of relevant policies and regulations. When conducting supervision work, the regulatory authorities should consciously pay attention to the information of external stakeholders such as corporate customers to prevent violations of laws and regulations, protect the interests of investors and promote the healthy development of the capital market and the improvement of the real economy.

- Help the regulatory authorities in the capital market to understand the role of corporate customer information disclosure, reaffirm the importance of improving the quality of information disclosure in the capital market, and provide some inspiration for the formulation of corporate external stakeholders' information disclosure policies.

\subsection{Possible Innovations}

- There are few studies in the existing literature that combine customer and corporate defaults. At present, most of the research on corporate violations at home and abroad is based on the influence of internal or external supervision, and the research in this paper is based on the external interests of enterprises. Research from the perspective of the relevant customers further expands the literature on the influencing factors of corporate violations and the economic consequences of customer concentration.

- This paper studies the impact of customer concentration on corporate irregularities in light of China's unique national conditions and institutional background. At the same time, this paper also studies whether there is a significant difference in the degree of influence of customer concentration on corporate violations under different property rights and industry competition levels. What's more, this paper enriches the research of domestic related literatures from the perspective of customer concentration on the financial distress effect and governance effect of enterprises.

\section{Literature Review}

There are many foreign and domestic studies on the customer concentration and 
corporate violation which mainly focused on the economic consequences of customer concentration and ignored the impact of external stakeholders on the corporate concentration.

\subsection{Customer Concentration Literature}

Foreign research on customer concentration has started earlier than in China, so foreign literature on customer concentration topics is more extensive. Based on a review of previous literature, customer concentration studies have generally focused on the economic consequences of customer concentration on corporate information disclosure, earnings management, company performance, and financial decisions. Considering the wide range of literature on customer concentration in the past, the article sorts out previous research on customer concentration related to this article.

As for the foreign related research, Porter (1979) included supplier bargaining power and customer bargaining power into the five-force model as two factors to analyze the company's competitiveness, and pointed out that the company's bargaining power is closely related to its profit rate [1]. In the 1980s, the concept of bargaining power is introduced to explore the scope of the supply chain; scholars have begun to pay attention to the bargaining power in the supply chain downstream company in the role of the game. Since the cost of obtaining raw materials will be directly affected by the supplier's bargaining power, and the selling price of the company's products will be directly affected by the bargaining power of the customers, the bargaining power of suppliers and customers will inevitably affect the overall performance of the company. Raman and Shahrur's (2008) study shows that in order to maintain a cooperative relationship with customers, companies can influence their customers' perceptions of their future through upward earnings management because poor financial conditions of a company can reduce its ability to perform implicit contracts, and customers generally do not choose to trade with companies that may have financial difficulties [2]. Crawford et al. (2016) explored the role of customer concentration in public disclosure. He found that large customers can obtain private information of enterprises at a lower cost and reduce their demand for public information [3]. Therefore, the concentration of customers is negatively correlated with the number of public disclosures of enterprises. When the company has strong reliance on major customers, that is, when the customer concentration is high, the company's asset-liability ratio increases, the cash flow risk increases, and the possibility of financial distress increases. Itzkowitz (2013) pointed out that the reason why companies hold more cash may be the additional operational risk caused by preventing the default of their major customers, and the importance of customers will increase their cash holdings. In addition, he also pointed out that the company's holding of additional cash may also be a guarantee signal to help reduce the risk of customer churnrate [4].

As for the domestic related research, Tang Yuejun (2009) believes that the higher the concentration of suppliers and customers, the stronger their bargain- 
ing power, the worse the company's performance; the concentration between supplier concentration and bargaining power and company performance is one kind of inverted "U" shape relationship [5]. Zhang Min and Ma Lijun (2012) found that companies with higher customer concentration will provide more commercial credit to customers, thus making the company less valuable [6]. Zhang Sheng (2013) found that the higher the concentration of suppliers or customers, the worse the performance of the company due to the less holding of current assets and cash [7]. Lin Zhonggao, Tang Xieying (2015) analyzed the relationship between the company and major suppliers and customers from the perspective of specific investment, the results confirmed that the company's specific investment based on the cooperative relationship between the major suppliers and customers can promote the company's production efficiency; after analyzing the influencing factors of the company's diversified operation, it is further found that the higher the degree of diversification of the company, the relationship between the company and the customer is more dedicated to the company's production efficiency, at the same time, it will weaken the relationship between the company and the supplier [8].

\subsection{Corporate Violation Literature}

As for the foreign related research, Holderness (1988) found that many public companies in the United States are actually controlled by major shareholders behind the scenes [9]. Shleifer (1997) has done a detailed study on the ownership structure of the listed companies, pointing out that the company's business conflict based on principal-agent relationship has changed from the conflict between external investors and operators to the conflict between external investors and the controlling shareholder of the company, the reason is because the majority shareholders use the control of the company's operations to transfer resources from the listed company to themselves [10]. La Porta, Lopez and Shleifer (2000) use "tunneling" when describing the phenomenon that large shareholders transfer company resources from the company to their own hands, "Tunneling of the Controlling Shareholders" origins from this point, and its specific performance is excessively high managers' compensation, loan guarantees, and diluted equity [11]. Fan and T. J. Wong (2002) found the controlling shareholder of a listed company often manipulates the information to "smear" small and medium-sized shareholders, and its reliability of manipulating information disclosure is greatly reduced [12]. Sharma (2004) studied the financial fraud of institutional investors and companies in enterprises, and research shows that higher institutional shareholdings help companies reduce financial fraud [13]. An effective and common way to encourage executives is management shareholdings. Researchers believe that this kind of compensation incentive model is conducive to bundling the interests of managers and the interests of the company, and narrowing the differences of interests between principals and agents in the principal-agent theory. 
As for the domestic related research, China Securities Regulatory Commission has strict standards for companies to be listed, and listing has become a resource that many companies yearn for. Wu Liansheng and Wang Yaping (2007) found that China's listed companies in order to avoid government regulation, China's listed companies are exempted from delisting or processing, and have higher surplus in avoiding losses [14]. At the end, in order not to be rated as ST, ${ }^{\star}$ ST and PT companies by the China Securities Regulatory Commission, the loss-making companies have maintained their scarce listing resources by whitewashing financial statements to varying degrees, asset replacement and debt restructuring are common ways for loss-making companies to turn losses into profits.. The requirements of the CSRC for allotment or issuance conditions are "sustainable profits". Listed companies avoid the supervision of the CSRC by abusing related party transactions, profit management and surplus operations. Wang Xiongyuan and Guan Kaolei (2006) found that the audit committee is positively related to the quality of information disclosure [15]. Xue Zuyun, Huang Tong (2004) believes that companies with small or poor independence of the board of supervisors are more prone to financial disclosure violations, and companies with large size of the board of supervisors are more effective in monitoring information quality [16]. Lu Yao et al. (2016) found that when the influence of the CEO on the board of directors increases, the possibility of company violations increases. At the same time, the higher the degree of trust between people in the company's location, the weaker the influence of the CEO's influence on the board on the company's tendency to violate the company [17]. Teng Fei et al. (2016) found that product market competition has an "inducing" effect on corporate violations, that is, the higher the degree of competition in the product market of the company, the higher the company's tendency to violate the rules, the "induction" effect of product market competition on company violations is more obvious in business violations [18]. Cao Chunfang et al. (2017) found that the improvement of judicial independence not only increased the probability of the company being investigated for violations, but also increased the negative reaction of the company's violation of the regulations [19]. Zhai Dong et al. (2017) found that companies that hire government-invested independent directors have a higher tendency to violate the rules, and the probability of violations being audited is lower; companies that hire university-dealer-type independent directors have a lower tendency to violate regulations, and the probability of violations being audited is not lower [20].

\subsection{Literature Summary}

Based on the above literature review of customer concentration and corporate violations, we can learn that the research on the economic consequences of customer concentration generally focus on the economic consequences of customer concentration on corporate information disclosure, earnings management, company performance, financial decision-making, and less attention to the im- 
pact of customer concentration on corporate violations. The previous researches on the causes of corporate violations can be divided into major shareholders' tunneling theory, earnings management theory and excess income theory. In the past, the literature mainly focused on the impact of corporate shareholding structure, executive characteristics and board structure on corporate violations but ignored the impact of the company's key external stakeholder customers on corporate violations. Therefore, the research in this paper aims to supplement the research on the impact of customer concentration on corporate violations, identify the influencing factors of corporate violations, understand the economic consequences of customer concentration, promote the standardized operation of listed companies, and promote the healthy development of capital markets to improve the real economy.

\section{Research and Analysis}

\subsection{Customer Concentration and Corporate Violations}

The customer is an important external stakeholder of the company, which has an important impact on the daily operation and decision-making of the enterprise. And the concentration of customers in an enterprise is mainly affected by factors such as the shareholder composition, size, concentration of the operation plan, and the funds of the company. Through the review and analysis of the relevant research literatures in the past, it is found that the influence of customer concentration on corporate violations mainly comes from two aspects: financial distress effects and governance effects.

On the one hand, the effect of customer concentration on the financial distress of the company will increase the likelihood of corporate violations. As an important strategic partner of the company, as the concentration of customer increases, the bargaining power of customers gradually increases. In the negotiation process, the supplier companies in the inferior position are forced to make concessions providing lower prices and higher credit sales to large customers, which leads to a decline of the company's profitability. In this case, the management of companies with high customer concentration has a strong incentive to smooth performance and whitewash performance through earnings management or even financial fraud. Secondly, customers are more inclined to cooperate with companies with better financial status. In order to deliver good financial status to customers, enterprises may win the recognition of big customers by fictitious profits, false assets, and false information. Therefore, from the perspective of financial distress effects, customer concentration will increase the likelihood of corporate violations.

On the other hand, the governance effect of customer concentration on the company will reduce the possibility of corporate violations. Firstly, in order to avoid costly loss of big customers, companies will tend to work hard to maintain relationships with large customers and provide customers with more information they need to facilitate information sharing along the supply chain and im- 
prove the coordination of the supply chain, thereby reducing the information asymmetry between customers and suppliers. Secondly, in the long-term cooperative relationship, the company can also obtain more accurate customer information, which can make more accurate production forecasting, reduce inventory management costs, and improve inventory management efficiency and working capital management efficiency. At the same time, because either the suppliers or the customers are bankrupt and liquidated, the other party has to bear the corresponding costs. If the supplier goes bankrupt, its impact on the big customers is also fatal. The customer will actively participate in the company management for his own interests, actively pay attention to the company's operating status and financial status, and play an external supervision role for the company, thus to a certain extent relieve agency conflicts within the enterprise. Therefore, from the perspective of governance effects, customer concentration will increase the likelihood of corporate violations.

\subsection{Property Rights, Customer Concentration and Corporate Violations}

From the transition of the socialist planned economy to the socialist market economy, China has produced township enterprises, individual and private enterprises, and foreign-funded enterprises. According to the scientific division method, they should be collectively referred to as the non-state-owned economy. From the perspective of the owner, companies can be divided into state-owned enterprises and non-state-owned enterprises. Non-state-owned enterprises include private enterprises, foreign companies, and joint ventures. In the context of China's national conditions and special systems, although China has gradually implemented state-owned reforms, state-owned enterprises have more self-management rights, but the natural relationship between state-owned enterprises and the government makes their business objectives still not only include the financial business performance but also cooperating with the government to undertake more social and political tasks due to government control, because the government controls their equity, personnel rights and other important powers. On the other hand, state-owned enterprises are not simply market entities that aim at maximizing value or maximizing profits, but have multiple objectives, one of the most important ones is to bear a certain policy burden for the government and maintain social stability. These characteristics of state-owned enterprises determine that their corporate violations will be more constrained. Therefore, the impact of customer concentration on corporate violations may vary under different property rights.

On the one hand, the nature of property rights will have a deterrent effect on the impact of customer concentration on corporate violations. First, due to the relationship between state-owned enterprises and the government, customers generally tend to cooperate with state-owned enterprises with lower risks and more secure operations. Second, because state-owned enterprises need to cooperate with the government to undertake more social and political tasks, they are 
subject to more restrictions on corporate compliance operations. Finally, due to the special relationship between state-owned enterprises and the government, they will be subject to more social media supervision and will also pay more attention to their social image. Therefore, in terms of corporate compliance, they will comply with regulations to conduct business operations.

On the other hand, non-state-owned enterprises, because their enterprise strength is generally weaker than state-owned enterprises and their main business goal is to maximize corporate value, non-state-owned enterprises are more likely to fall into financial difficulties due to large customers, and corporate irregularities such as whitewashing profits, financial fraud, and disclosure of false information occur. Therefore, the nature of property rights will have a restraining effect on the impact of corporate customer concentration on corporate violations.

Whether it is a state-owned enterprise or a non-state-owned enterprise, the customer is an important external stakeholder for them, and both will be supervised by the client. However, for state-owned enterprises, because they pay more attention to their public image, the impact of corporate violations will be greater, and the governance effect of customers on state-owned enterprises should be stronger. Therefore, the nature of property rights will have a promoting effect on the suppression of corporate customer concentration on corporate violations.

\section{Research Conclusions and Limitations}

Through the literature review of this paper, we can conclude that domestic and foreign research still lacks research on customer concentration and corporate violations, and future research can be further studied in this area. After the analysis of this paper, customer concentration has two effects on corporate violations: financial distress effect and governance effect, but which effect is more influential, and which will be a direction for future research still need to be discussed. At the same time, through further discussion and analysis in this paper, the paper concludes that whether it is the financial distress effect or the governance effect, the nature of the property rights of the enterprise will have a significant impact on the relationship between customer concentration and corporate violations.

However, there are still some limitations in this paper, and further research is needed in the future. For example, customer concentration can have an impact on corporate violations; then what factors affect customer compliance by the degree of customer concentration? This is an issue that can be explored in the future. At the same time, in future research, the empirical data of listed companies can also be used to test the viewpoints of this article.

\section{Conflicts of Interest}

The author declares no conflicts of interest regarding the publication of this paper. 


\section{References}

[1] Porter, M.E. (1979) How Competitive Forces Shape Strategy. Harvard Business Review, 59, 137-145.

[2] Raman, K. and Shahrur, H. (2008) Relationship-Specific Investments and Earnings Management: Evidence from Corporate Suppliers and Customers. The Accounting Review, 83, 1041-1081. https://doi.org/10.2308/accr.2008.83.4.1041

[3] Crawford, S., Huang, Y., et al. (2016) Customer Concentration and Public Disclosure: Evidence from Management Earnings Forecasts. Social Science Electronic Publishing. https://papers.ssrn.com/sol3/papers.cfm?abstract_id=2781627

[4] Itzkowitz, J. (2013) Customers and Cash: How Relationships Affect Supplier's Cash Holdings. Journal of Corporate Finance, 19, 159-180. https://doi.org/10.1016/j.jcorpfin.2012.10.005

[5] Tang, Y.J. (2009) Supplier, Dealer Bargaining Power and Company Performance-Empirical Evidence from Chinese Manufacturing Listed Companies from 2005 to 2007. China's Industrial Economy, 10, 67-76.

[6] Zhang, M., Ma, L.Z. and Zhang, S. (2012) Supplier-Customer Relationship and Auditor Selection. Accounting Research, 12, 81-86.

[7] Zhang, S. (2013) Supplier-Customer Relationship and Asset Structure: Empirical Evidence from Listed Companies in China's Manufacturing Industry. Accounting Forum, 1, 89-99.

[8] Lin, Z.G and Tang, X.Y. (2015) Diversification, Relationship-Specific Investment and Corporate Productivity-Empirical Evidence Based on Key Supplier and Customer Perspectives. Journal of Hebei University of Economics and Business, 36, 90-97.

[9] Holderness, C.G. and Sheehan, D.P. (1988) The Role of Majority Shareholders in Publicly Held Corporations: An Explanatory Analysis. Journal of Financial Economics, 20, 317-346. https://doi.org/10.1016/0304-405X(88)90049-9

[10] Shleifer, A. and Vishny, R.W. (1997) A Survey of Corporate Governance. The Journal of Finance, 52, 737-783. https://doi.org/10.1111/j.1540-6261.1997.tb04820.x

[11] La Porta, R., Lopez-de-Silanes, F., Shleifer, A. and Vishny, R. (2000) Investor Protection and Corporate Governance. Journal of Financial Economics, 58, 3-27. https://doi.org/10.1016/S0304-405X(00)00065-9

[12] Wong, T.J. and Joseph, F. (2002) Corporate Ownership Structure and the Informativeness of Accounting Earnings in East Asia. Journal of Accounting and Economics, 33, 401-425. https://doi.org/10.1016/S0165-4101(02)00047-2

[13] Sharma, V.D. (2004) Board of Director Characteristics, Institutional Ownership, and Fraud: Evidence from Australia. Auditing. A Journal of Practice \& Theory, 23, 105-117. https://doi.org/10.2308/aud.2004.23.2.105

[14] Wu, L.S. and Wang, Y.P. (2007) Estimation Model and Empirical Evidence of Earnings Management: A Review. Economic Research, 8, 143-152.

[15] Wang, X.Y. and Guan, K.L. (2006) Empirical Research on the Characteristics of Audit Committee and the Quality of Information Disclosure. Audit Research, 6, 42-49.

[16] Xue, Z.Y. and Huang, W. (2004) System Characteristics of Board of Directors and Board of Supervisors and Quality of Accounting Information: Empirical Analysis from China's Capital Market. Finance and Economics Theory and Practice, 25, 84-89. 
[17] Lu, Y. and Li, C. (2016) CEO's Influence on the Board of Directors and Violations of Listed Companies. Financial Research, 1, 176-191.

[18] Teng, F., Xin, Y. and Gu, X.L. (2016) Product Market Competition and Listed Company Violations. Accounting Research, 9, 32-40

[19] Cao, C.F., Chen, L.L. and Zhang, T.T. (2017) “The Name of Law”: Improvement of Judicial Independence and Corporate Violations. Financial Research, 5, 191-206.

[20] Zhai, D., Xie, W. and Yang, D. (2017) Background Type of Independent Directors and Research on Violations of Listed Companies. Accounting Research, 8, 55-61. 